\title{
Hepatitis B virus transmission in pre-adolescent schoolchildren in four multi-ethnic areas of England
}

\author{
M. A. BALOGUN ${ }^{1 *}$, J. V. PARRY ${ }^{2,3}$, K. MUTTON ${ }^{4}$, C. OKOLO ${ }^{5}$, L. BENONS $^{5}$, \\ H. BAXENDALE ${ }^{6}$, T. HARDIMAN ${ }^{6}$, E. H. BOXALL ${ }^{7,8}$, J. SIRA $^{8}$, M. BROWN ${ }^{8}$, \\ S. BARNETT ${ }^{2}$, U. GUNGABISSOON ${ }^{1}$, A. WILLIAMS ${ }^{9}$, D. A. KELLY, \\ S. VIJERATNAM ${ }^{10}$, S. IJAZ ${ }^{2}$, B. TAYLOR ${ }^{6}$, C. G. TEO ${ }^{2}$ AND M. E. RAMSAY ${ }^{1}$ \\ ${ }^{1}$ Immunisation, Hepatitis and Blood Safety Department, Health Protection Services Division, Health Protection \\ Agency, London, UK; ${ }^{2}$ Virus Reference Department, Microbiology Services Division, Health Protection Agency, \\ London, UK; ${ }^{3}$ Department of Public Health and Policy, London School of Hygiene and Tropical Medicine, \\ London, UK, ${ }^{4}$ North West-Microbiology Services Division, Health Protection Agency, Manchester, UK, \\ ${ }^{5}$ Bury and Rochdale Health Authority, Manchester, UK; ${ }^{6}$ General and Adolescent Paediatric Unit, University \\ College London, Institute of Child Health, London, UK, ${ }^{7}$ West Midlands - Microbiology Services Division, \\ Health Protection Agency, Birmingham, UK; ${ }^{8}$ Paediatric Liver Unit, Birmingham Children's Hospital NHS \\ Foundation Trust, Birmingham, UK; ${ }^{9}$ National Health Service Enfield, Enfield, Middlesex, UK; ${ }^{10}$ Barnet and \\ Chase Farm Hospitals NHS Trust, Hertfordshire, UK
}

Received 26 January 2012; Final revision 18 April 2012; Accepted 11 June 2012; first published online 31 July 2012

\section{SUMMARY}

The aim of this study was to estimate the amount of childhood hepatitis B virus transmission in children born in the UK, a very low-prevalence country, that is preventable only by universal hepatitis B immunization of infants. Oral fluid specimens were collected from schoolchildren aged 7-11 years in four inner city multi-ethnic areas and tested for the presence of antibody to hepatitis B core antigen (anti-HBc). Those found positive or indeterminate were followed up with testing on serum to confirm their hepatitis B status. The overall prevalence of anti-HBc in children was low [0.26\%, $95 \%$ confidence interval (CI) $0 \cdot 14-0 \cdot 44]$. The estimated average annual incidence of hepatitis B was estimated to be $29 \cdot 26 / 100000$ children (95\% CI 16.00-49.08). The total incidence that is preventable only by a universal infant immunization programme in the UK was estimated to be between $5 \cdot 00$ and $12 \cdot 49 / 100000$. The study demonstrates that the extent of horizontal childhood hepatitis B virus transmission is low in children born in the UK and suggests that schools in the UK are an uncommon setting for the transmission of the virus. Targeted hepatitis B testing and immunization of migrants from intermediate- and high-prevalence countries is likely to be a more effective measure to reduce childhood transmission than a universal infant immunization programme.

Key words: Children, ethnic groups, hepatitis B, horizontal transmission, public health, schools.

\footnotetext{
* Author for correspondence: Dr M. A. Balogun, Health Protection Agency, Immunisation, Hepatitis and Blood Safety Department, 61 Colindale Avenue, London NW9 5EQ, UK.

(Email: koye.balogun@hpa.org.uk)
} 


\section{INTRODUCTION}

Chronic infection with hepatitis B virus (HBV) affects over 350 million individuals worldwide and is the leading cause of hepatocellular carcinoma and liver cirrhosis [1-3]. Universal infant immunization has decreased rates of $\mathrm{HBV}$ infection in a number of high-prevalence countries [4-6]. In low-prevalence countries, however, perinatal transmission can be largely prevented by universal antenatal screening and targeted immunization of neonates [7-9]. Infections in adult risk groups can be targeted by selective immunization programmes or by universal adolescent immunization. Such programmes, however, cannot prevent horizontal transmission of the virus in early childhood.

Most new infections acquired in the UK, a lowprevalence country, are believed to occur in adults primarily via injecting drug use or sexual transmission $[10,11]$. The extent of horizontal transmission in the UK, particularly during early childhood, is unknown. In low-endemicity countries, prevalence is higher in migrant populations $[12,13]$. Horizontal transmission is more common in countries where there is a high or intermediate prevalence of hepatitis B infection [14-16] and families with origins in such countries may experience a higher incidence of both acute and chronic infection than the general population [17]. Studies in high- and intermediate-prevalence areas have also shown that the risk of horizontal transmission of HBV in the household occurs prior to and during school years between the ages of 7 and 11 years $[1,18]$.

If horizontal transmission commonly occurred in the household and school setting in the UK, a high proportion of children attending school in districts with large ethnic minority populations would be expected to have markers of exposure to the virus. Oral fluid samples provide a non-invasive alternative to blood for determining immunity and exposure to HBV in the general population. A number of studies have shown the feasibility and acceptability of oral fluid collection for use in the surveillance of viral disease in children [19-21]. This paper describes such a study to estimate the amount of transmission of $\mathrm{HBV}$ in multi-ethnic schoolchildren in the UK that is preventable only by a universal infant hepatitis B immunization programme commencing at age 2 months alongside other infant vaccines.

\section{METHODS}

A cross-sectional study was conducted in four multiethnic areas of England: Bury \& Rochdale (Greater Manchester), Birmingham (West Midlands), Camden \& Islington (north London) and Enfield (north London). The study was conducted in four sequential phases in each area between 2001 and 2005. Children aged 7-11 years were recruited from schools selected through each local education authority on the basis of a multi-ethnic pupil population. Schools that agreed to participate were provided with further information about the study, and presentations about the study were provided for teachers in all areas. In Birmingham, face-to-face presentations for children were also provided.

Consent forms were given to children to take home for their parents to complete. The documentation for parents included information about hepatitis $\mathrm{B}$, the study design and objectives and was translated into common languages encountered in three areas. In the Birmingham area school link workers assisted with issues around language. Information about hepatitis $\mathrm{B}$ and the study was also provided for the children. Parents were invited to complete a short questionnaire requesting demographic information about the child (age, gender, country of birth, ethnic group and country of birth of each parent). Children whose parents returned signed consent forms were recruited into the study. The OraSure ${ }^{\circledR}$ Oral Specimen Collection Device (OraSure Technologies Inc., USA) was used to collect an oral fluid sample from each child participating in the study. This device consists of an absorbent cotton fibre pad affixed to a nylon stick. Children were asked to take their own oral fluid specimen by placing the pad inside the mouth (between the lower gum and cheek) and rubbing back and forth gently several times along the gum line until the pad was moist. The pad was then left stationary within the mouth for $2 \mathrm{~min}$ before being placed in a vial of preservative solution provided as part of the device. Staff from the study team and school nurses were present to provide assistance. The oral fluid specimens were returned to the Centre for Infections, Virus Reference Department (HPA Microbiology Services Division, Colindale, London) for oral fluid extraction and testing for antibody to the hepatitis B core antigen (anti-HBc). During the course of the study two different anti-HBc assays based on IgG class-specific antibody-capture techniques were used to determine status. In three areas oral fluid 
was tested for anti-HBc by the Abbott Murex ICE ${ }^{\mathrm{TM}}$ $\mathrm{HBc}$ (Murex Biotech Ltd, UK) assay according to the manufacturer's guidelines. This enzyme immunoassay detected both $\mathrm{IgG}$ and $\mathrm{IgM}$ against $\mathrm{HBc}$ antigen. During the investigation Murex Biotech discontinued manufacture of the ICE HBc assay, so, for the final area, Enfield, an 'in-house' $\operatorname{IgG}$ antibody capture radioimmunoassay (GACRIA) was used to detect the presence of $\mathrm{IgG}$ anti-HBc in oral fluid specimens $[22,23]$. Both assays had previously been validated in comparison to serum specimens. The enzyme immunoassay had a sensitivity of $82 \%$ and a specificity $>99 \%$, while the GACRIA had a sensitivity of $92 \%$ and specificity of $100 \%[24,25]$. Specimens reactive on the Abbott Murex ICE HBc assay were also tested with the GACRIA.

Follow-up serum specimens were collected from any schoolchildren who were found to be oral-fluid anti-HBc reactive or indeterminate on the Murex assay or GACRIA. Serum was also collected from household family members of schoolchildren whose follow-up serum specimen was confirmed to contain anti-HBc. All serum specimens were tested for hepatitis B surface antigen (HBsAg) (Hepanostika Microelisa system, Organon Teknika, The Netherlands) and for total anti-HBc ('in house' competitive radioimmunoassay). Those that were either HBsAg or total anti-HBc positive were then tested for antibody to the hepatitis B core antigen IgM subclass (anti-HBc IgM) (Murex Biotech Ltd), hepatitis B e antigen (HBeAg) (Organon Teknika) and antibody to hepatitis e antigen (anti-HBe) (Organon Teknika). Specimens that were $\mathrm{HBsAg}$ negative and total anti-HBc positive were tested for antibody to hepatitis B surface antigen (anti-HBs) (Abbott Laboratories, UK). All serum specimens that had serological markers for hepatitis B were screened for HBV DNA. Sequence analysis was undertaken across part of the HBsAg and core regions on HBV DNA-positive samples as described previously [26].

The study children and their household members confirmed as anti-HBc positive on serum testing were subsequently placed in one of three categories on the basis of HBsAg and/or anti-HBc IgM findings: persistent infection (HBsAg positive, anti-HBc positive, anti-HBc IgM negative); acute infection (HBsAg positive, anti-HBc positive, anti-HBc IgM positive); resolved infection (HBsAg negative, anti-HBc positive). Information on exposure risks from birth was obtained for study children confirmed as being serologically positive. Families were interviewed by members of the investigation team concerning these exposure risks and information collected using a structured questionnaire. Family members of anti$\mathrm{HBc}$ seropositive study children found to be susceptible were offered hepatitis $\mathrm{B}$ vaccine. Individuals identified as having a serological profile indicative of acute, persistent or resolved infection were referred to a liver specialist.

\section{Statistical analysis}

Prevalence estimates were calculated for the prevalence of anti-HBc and HBsAg based on serologically confirmed results and confidence intervals were calculated using the exact binomial distribution.

To estimate the average annual incidence of hepatitis B in children in these areas, the person-years at risk (calculated as the sum of the ages for all the children tested) was used as the denominator and the numerator was the number of children with confirmed markers of persistent, acute, or resolved hepatitis B infection irrespective of country of birth. The average annual incidence was estimated for UK-born children overall and for each area of the study. To estimate the number of such cases preventable only by a universal infant immunization programme in the UK, incidence in UK-born children was calculated in the same way but first excluding those whose mothers were persistently infected and second, also excluding those whose mothers had a resolved past infection. As an infant prevention programme in the UK would be likely to be given in the first 6 months of life, one implicit assumption was that infections in non-UK-born children would not have been preventable by immunization in early infancy (as most children arrive in the UK after that age). In addition, it was assumed that infections in children whose mothers had evidence of persistent infection would be preventable by the current policy of universal antenatal screening and targeted immunization at birth. In contrast, infections in children whose mothers showed evidence of resolved infection would only have been preventable by the targeted programme if the mother had been HBsAg positive at the time of antenatal screening. Incidence was therefore estimated both including and excluding infection in children of mothers with resolved infections.

Confidence intervals were calculated using the exact binomial distribution and applied accordingly. 


\begin{tabular}{|c|c|c|c|c|}
\hline & \multicolumn{4}{|l|}{ Study area } \\
\hline & $\begin{array}{l}\text { Bury \& } \\
\text { Rochdale }\end{array}$ & $\begin{array}{l}\text { Camden \& } \\
\text { Islington }\end{array}$ & Birmingham & Enfield \\
\hline No. of questionnaires returned & 1240 & 974 & 2110 & 1337 \\
\hline No. of specimens tested & 1222 & 715 & 2096 & 1301 \\
\hline No. reactive for anti-HBc in oral fluid & 4 & 3 & 11 & 12 \\
\hline No indeterminate for anti-HBc in oral fluid & 0 & 1 & 0 & 0 \\
\hline No. followed up for serum testing & 4 & 4 & 9 & 11 \\
\hline No. negative for anti-HBc in serum & 0 & 1 & 6 & 7 \\
\hline No. confirmed anti-HBc-positive in serum & 4 & 3 & 3 & 4 \\
\hline \multicolumn{5}{|l|}{ Final serological status } \\
\hline Resolved & 3 & 3 & 2 & 4 \\
\hline Persistent & 1 & 0 & 1 & 0 \\
\hline
\end{tabular}

\section{Ethical approval}

Ethical approval for the study was obtained from local ethics committees as well as the London MultiCentre Research Ethics Committee and the Public Health Laboratory Service Ethics Committee.

\section{RESULTS}

Of 9942 questionnaires and consent forms sent, a total of $5661(56.9 \%)$ were returned from the four areas investigated. Overall 5334 children, 2790 (52.3\%) females and $2520(47 \cdot 2 \%)$ males were tested for anti-HBc (in 24 sex was not stated).

The age of the 5334 tested children ranged from 7 to 11 years (median 9 years, $n=5263$ ) while their family household sizes ranged from 2 to 20 persons (median $5, n=4928)$. Of the 5334 children tested, $4464(83 \cdot 7 \%)$ were UK born, $729(13.7 \%)$ were non-UK born and in the remaining $141(2 \cdot 6 \%)$ information on country of birth was not reported. A total of $2801(62.7 \%)$ UK-born children from all four areas of the study that were tested for anti-HBc had at least one parent born in a country with intermediate or high HBV prevalence.

Thirty-one children were reactive or indeterminate for anti-HBc on oral fluid testing. Serological followup was completed for 28 ; two had persistent infection (HBsAg positive), 12 had resolved infection (HBsAg negative, confirmed anti-HBc positive) and the remaining 14 were anti-HBc negative (Table 1). The three that were not followed up did not respond to any further requests for additional testing and were excluded from further analysis (and from the denominator). The prevalence of chronic infection was
$0 \cdot 038 \%$ [95\% confidence interval (CI) $0 \cdot 0045-0 \cdot 14]$ with $0 \cdot 26 \%(95 \%$ CI $0 \cdot 14-0 \cdot 44)$ of the eligible study children having evidence of exposure to HBV. The prevalence of exposure to hepatitis B was low in all ethnic groups tested but was higher in those born outside than inside the UK (Table 2).

The average annual incidence of hepatitis $\mathrm{B}$ was estimated to be $29 \cdot 26 / 100000$ (95\% CI $16 \cdot 00-49 \cdot 08$ ) overall and $14 \cdot 99 / 100000$ (95\% CI $5 \cdot 50-32 \cdot 61 /$ $100000)$ for UK-born children. The estimated incidence in UK-born children was low in all four areas, ranging from $0 / 100000(95 \%$ CI $0 \cdot 0-63 \cdot 85), 6 \cdot 19 /$ 100000 (95\% CI 0·16-34.45), 12.53/100 000 (95\% CI $0 \cdot 32-69 \cdot 77)$ and $39 \cdot 55 / 100000(95 \%$ CI $10 \cdot 78-101 \cdot 23)$ in Camden \& Islington, Birmingham, Enfield, and Bury \& Rochdale, respectively.

Of the 14 children with confirmed current or resolved HBV infection, eight were born overseas and arrived in the UK between ages 5 and 10 years (Table 3). Of the six UK-born children, in only one case (case 8) was the mother shown to be persistently infected. In eight families (cases 1, 2, 8, 10, 11, 12, 13, 14), there was evidence of past and current infection in siblings. Molecular typing of the virus causing persistent infection in the families of cases 1 and 2 showed the viruses to belong to genotypes $\mathrm{D}$ and $\mathrm{A}$, respectively (data not shown). The viral sequences were identical within each family group, suggesting that infection was acquired from a common source within or outside the family setting.

All of the children found to be anti-HBc positive had risk factors such as travelling to an intermediateor high-prevalence country, receiving therapeutic injections, having the head shaved and/or having been circumcised in those countries. Assuming that all 
Table 2. Number of children tested using oral fluid and confirmed to be anti-HBc serum positive by ethnic group and country of birth

\begin{tabular}{|c|c|c|c|c|c|c|}
\hline \multirow[b]{2}{*}{ Ethnic group } & \multirow[b]{2}{*}{$\begin{array}{l}\text { No. } \\
\text { tested* }\end{array}$} & \multicolumn{2}{|c|}{ UK-born } & \multicolumn{2}{|c|}{ Non-UK-born } & \multirow{2}{*}{$\begin{array}{l}\text { Total no. } \\
\text { serum positive } \\
(\%)\end{array}$} \\
\hline & & $\begin{array}{l}\text { No. } \\
\text { tested }\end{array}$ & $\begin{array}{l}\text { No. serum } \\
\text { positive }\end{array}$ & $\begin{array}{l}\text { No. } \\
\text { tested }\end{array}$ & $\begin{array}{l}\text { No. serum } \\
\text { positive }\end{array}$ & \\
\hline Bangladeshi & 560 & 484 & 1 & 59 & 2 & $3(0 \cdot 5 \%)$ \\
\hline Black African & 284 & 135 & 0 & 129 & 4 & $4(1 \cdot 4 \%)$ \\
\hline Black Caribbean & 381 & 298 & 0 & 75 & 1 & $1(0 \cdot 3 \%)$ \\
\hline Chinese & 30 & 27 & 0 & 3 & 0 & 0 \\
\hline Indian & 639 & 591 & 1 & 36 & 0 & $1(0 \cdot 2 \%)$ \\
\hline Pakistani & 1150 & 1047 & 4 & 85 & 0 & $4(0 \cdot 4 \%)$ \\
\hline White & 1421 & 1272 & 0 & 132 & 1 & $1(0 \cdot 1 \%)$ \\
\hline Other & 804 & 568 & 0 & 203 & 0 & 0 \\
\hline Not stated & 65 & 42 & 0 & 7 & 0 & 0 \\
\hline Total & 5334 & 4464 & $6(0 \cdot 13 \%)$ & 729 & $8(1 \cdot 10 \%)$ & $14(0 \cdot 26 \%)$ \\
\hline
\end{tabular}

* Includes country of birth not reported.

cases in UK-born children where the mother was not persistently infected would have been preventable by targeted perinatal immunization, the incidence of infection preventable only by a universal infant programme in the UK was estimated to be $12 \cdot 49 / 100000$ (95\% CI 4.05-29·13). If we assume that infections in the three children (cases 1,3,7) where the mother had resolved infection were also acquired perinatally, then the estimated incidence preventable only by a universal programme would be lower at 5.00/100000 (95\% CI 0.60-18.04).

\section{DISCUSSION}

The prevalence of hepatitis B and the extent of horizontal transmission of $\mathrm{HBV}$ in schoolchildren in England is low. In this study the prevalence of anti$\mathrm{HBc}$, indicative of past or current $\mathrm{HBV}$ infection, was only $0.26 \%(95 \%$ CI $0 \cdot 14-0 \cdot 44)$, and was lower in UK-born than non-UK-born children. When estimating the potential benefit of a universal infant hepatitis B immunization programme, it was assumed that infections in non-UK-born children were unlikely to be preventable. This assumption was confirmed by the observation that all infected children born outside the UK migrated after the age of 6 months, and so would have missed a routine infant schedule. In addition, we assumed that the single persistent infection detected in a UK-born child whose mother had a resolved infection would have been preventable through universal antenatal screening and targeted immunization. However, it could be argued that with a universal immunization programme, a higher coverage would be achieved than in the current selective programme. Nonetheless, as a universal programme would probably commence with other infant vaccines at the age of 2 months, it is likely that a universal approach would be ineffective in preventing perinatal transmission. For the children whose mothers had evidence of resolved infection, it is possible that the mother may have been HBsAg positive in the antenatal period. If so, then the child may have been offered immunization in the targeted programme. The finding of infected siblings in families where the mother had resolved infection, however, may suggest that only some children were infected perinatally or that these infections were acquired postnatally from a single source. Based on these arguments, the total incidence of hepatitis B that would only be prevented by a universal infant immunization programme in the UK was estimated to be between $5 \cdot 00$ and $12 \cdot 49 / 100000$. As the four geographical areas were chosen on the basis of their multi-ethnic population, it is likely that this represents a higher incidence than in other parts of the UK.

An earlier UK-based serological study using residual samples in children aged 13-14 years found an overall anti-HBc prevalence of $0.7 \%$ and an $\mathrm{HBsAg}$ prevalence of $0 \cdot 1 \%$ [27]. Unlike this previous study, we were able to collect additional demographic details to investigate the effect of ethnicity and country of birth on the prevalence of exposure to HBV. The oral fluid specimens tested in this study came from school populations in urban areas with large ethnic minority populations. The majority of the children in the study 
Table 3. Summary of children with evidence of current and past HBV infection and results of family testing

\begin{tabular}{|c|c|c|c|c|c|c|c|c|}
\hline $\begin{array}{l}\text { HBV infection } \\
\text { status of case }\end{array}$ & $\begin{array}{l}\text { Case } \\
\text { no. }\end{array}$ & $\begin{array}{l}\text { Age } \\
\text { (years) }\end{array}$ & Sex & Ethnic origin & $\begin{array}{l}\text { Place of birth } \\
\text { (age in years at } \\
\text { migration for } \\
\text { non-UK-born children) }\end{array}$ & $\begin{array}{l}\text { Maternal HBV } \\
\text { infection status }\end{array}$ & $\begin{array}{l}\text { No. family } \\
\text { members } \\
\text { tested }\end{array}$ & $\begin{array}{l}\text { Family members } \\
\text { with HBV infection }\end{array}$ \\
\hline \multirow[t]{2}{*}{ Persistent infection } & 1 & 11 & Female & Pakistani & UK & Resolved infection & 7 & $\begin{array}{l}3 \text { siblings with persistent infection, } \\
\text { father and sister-in-law } \\
\text { resolved infection }\end{array}$ \\
\hline & 2 & 11 & Female & Bangladeshi & Bangladesh (7) & Negative & 6 & $\begin{array}{l}1 \text { sibling with persistent } \\
\text { infection; father and } \\
3 \text { siblings with } \\
\text { resolved infection }\end{array}$ \\
\hline \multirow[t]{12}{*}{ Resolved infection } & 3 & 8 & Female & Indian & UK & Resolved infection & 5 & None \\
\hline & 4 & 10 & Male & Black-African & Angola (6) & Negative & 3 & None \\
\hline & 5 & 9 & Male & Black African & Portugal (6) & Negative & 1 & None \\
\hline & 6 & 10 & Female & Black African & Somalia (10) & Negative & 4 & Father with persistent infection \\
\hline & 7 & 8 & Male & Bangladeshi & UK & Resolved infection & 3 & None \\
\hline & 8 & 9 & Female & Pakistani & UK & Persistent infection & 5 & $\begin{array}{l}\text { Father and } 2 \text { siblings with } \\
\text { resolved infection }\end{array}$ \\
\hline & 9 & 8 & Male & Pakistani & UK & Negative & 10 & None \\
\hline & 10 & 10 & Male & Bangladeshi & Bangladesh (9) & Negative & 5 & $\begin{array}{l}1 \text { sibling with resolved } \\
\text { infection }\end{array}$ \\
\hline & 11 & 11 & Female & Black-African & Nigeria (10) & Resolved infection & 3 & $\begin{array}{l}2 \text { siblings with resolved } \\
\text { infection }\end{array}$ \\
\hline & 12 & 9 & Female & White & Kosovo (5) & Negative & 4 & $\begin{array}{l}\text { Father persistently infected, } \\
1 \text { sibling with resolved infection }\end{array}$ \\
\hline & 13 & 10 & Male & Pakistani & UK & Negative & 4 & $\begin{array}{l}\text { Father and } 1 \text { sibling with } \\
\text { resolved infection }\end{array}$ \\
\hline & 14 & 9 & Male & Black-Caribbean & Caribbean (4) & Resolved infection & 4 & $\begin{array}{l}1 \text { sibling persistent and } \\
1 \text { sibling resolved infection }\end{array}$ \\
\hline
\end{tabular}


had been born in the UK although for over half either one or both parents had been born in areas known to have a high or intermediate prevalence of chronic hepatitis B. Of the 14 children confirmed to be anti$\mathrm{HBc}$ positive after serological testing, eight were born overseas and only six were born in the UK. This suggests that infection with hepatitis B during childhood in the UK is unusual, even in these multi-ethnic populations. All UK-born children with evidence of past infection were from communities with origins of high or intermediate prevalence of chronic hepatitis B infection, suggesting that transmission at school is unusual. Children of parents from intermediate- and high-prevalence countries are potentially at risk from infectious parents or other relatives who reside or visit in their household and when returning to their parents' countries of birth for holidays [12, 28, 29]. In this study molecular sequencing confirmed evidence of intrafamilial spread and/or clustering of infection within two families.

In studies from China and Taiwan horizontal transmission has been shown to be responsible for about half of the individuals chronically infected with hepatitis B [30, 31]. These studies indicate that in these countries unsterilized therapeutic injections and intrafamilial spread from siblings are the major transmission routes among children in these countries. Most hepatitis B infections in sub-Saharan Africa in children are acquired through horizontal transmission, and a study from Ghana aimed to determine the behavioural factors associated with horizontal transmission [32].These factors included sharing of bath towels, sharing of chewing gum, sharing of dental cleaning materials and biting of fingernails in conjunction with scratching the backs of those with persistent infection.

In countries such as the UK that have substantial populations of ethnic minorities from intermediateand high-prevalence areas, migrants may continue to be vulnerable to some of the transmission routes present in their country of origin [33]. UK-based surveillance data have shown that the incidence of hepatitis B is higher in South Asian children compared to non-South Asian children [17]. Among South Asians the study showed that transmission within the household and while travelling were frequently reported routes of acquisition. A high incidence of HBV infection has been observed in UK-born children of Somali ethnicity resident in the UK suggesting that significant transmission during childhood may indeed occur among some UK ethnic minorities with origins in high- or intermediateprevalence countries [34]. In the Somali population studied, the authors found a high overall prevalence of active HBV infection (HBsAg positive) of $5.7 \%$. Seven $(8.7 \%)$ of the 80 children aged $<5$ years and born in the UK had evidence of exposure to hepatitis $\mathrm{B}$, of whom only one had a close family member identified as beimg HBsAg seropositive. These authors concluded that horizontal transmission may be continuing at an early age within the UK, and suggested community circumcision as a risk factor for hepatitis B transmission. They recommended that this population would benefit from surveillance, immunization and advice on best practice during circumcision procedures.

In the school setting a number of studies from lowprevalence countries have confirmed our findings that horizontal transmission outside the household is rare. A study from Denmark found an anti-HBc prevalence in serum of $0.8 \%$ in 2428 schoolchildren aged 6-16 years [35]. Of the $20 \mathrm{HBV}$-exposed children, 12 were immigrants and the remaining eight were born in Denmark. Three of the children, all immigrants, were HBsAg positive. These authors found no relationship between anti-HBc prevalence in Danish-born children and schools with high numbers of immigrant or HBsAg-positive children. The study also failed to show evidence of transmission of hepatitis B from immigrant schoolchildren to Danish-born schoolchildren. Another Danish study identified only one child (an immigrant from Somalia) with resolved infection in 585 preschool children where $55 \%$ were immigrants [36]. A study from Australia showed a low prevalence of $\mathrm{HBV}$ infection in low-risk schoolchildren irrespective of the proportion of high-risk children in their classes [37]. Other authors have concluded that concern about the risk of hepatitis B in schools is not well-founded [38] although the risk of transmission may be increased in nursery schools [39]. Studies on the epidemiology of hepatitis B in the USA, Sweden and England have demonstrated that despite increasing immigration there has been no demonstrable impact on the overall incidence of acute HBV infection [11, 40-42].

The results of this study do not support a hypothesis that a substantial amount of UK HBV childhood transmission would only be prevented by universal infant hepatitis B immunization. Childhood transmission is low and a universal infant programme would prevent a low number of infections. However, the study does indicate that active case-finding and 
selective immunization among children whose families originate from intermediate and high hepatitis B prevalence areas should be considered [43]. Casefinding would provide a means for identifying those who are persistently infected, and identify children and close contacts whose risk of HBV infection would be minimized through immunization.

The major burden of disease associated with hepatitis B is due to the development of persistent infection. As those who acquire hepatitis B during infancy have at least a $90 \%$ risk of developing persistent infection, control policies aimed at preventing perinatal and horizontal transmission during childhood are likely to maximize benefits to public health. A study from Ireland, a low-incidence country, suggests that universal infant immunization against $\mathrm{HBV}$ infection would be a cost-effective intervention [44]. Universal immunization prevents iatrogenic transmission of $\mathrm{HBV}$ and in the long term adult risks such as infection acquired sexually and through injecting drug use. Cost-effectiveness studies in England and Wales have been less favourable to a universal infant policy but alternative selective strategies, similar to those used for bacillus Calmette-Guérin (BCG) immunization warrant further exploration $[45,46]$. Data from this study can therefore be used in England and Wales to inform both a universal infant and adolescent immunization policy and the implementation of a selective policy based on ethnicity. The Netherlands initiated immunizing children of parents who had immigrated from intermediate- and high-prevalence countries because horizontal transmission was thought to be an important route of transmission within the family/household setting [47].

\section{CONCLUSIONS}

Migration of persistently infected individuals into the UK limits the success of universal infant immunization or a selective programme based on ethnicity and geographical location. Some authors have suggested that the burden of hepatitis B in the UK could be reduced more cost effectively by implementing universal programmes in the endemic areas where new immigrants originate [48]. Immunizing infants of persistently infected mothers identified through antenatal screening prevents the chronic state emerging in the child and also prevents horizontal transmission of hepatitis B in early childhood. Antenatal screening and targeted immunization of the infant in the UK is highly cost effective but there is a need to improve delivery of the immunization service, and to use the identification of antenatal women to ensure screening and immunization of other family members $[9,49,50]$. To ensure hepatitis B is effectively controlled universal antenatal screening should be continued, children born to HBsAg-positive mothers should be immunized, selective immunization optimized and new migrants from intermediate- and high-prevalence countries targeted for screening, immunization and education with respect to $\mathrm{HBV}$.

\section{ACKNOWLEDGEMENTS}

We thank the schools and local educational authorities that contributed to this study. We also thank Dr Marko Petrovic for assistance with the follow-up of children in Bury \& Rochdale and Professor Geoffrey Dusheiko for providing clinical care for patients from Camden \& Islington. This study was funded by the Department of Health.

\section{DECLARATION OF INTEREST}

None.

\section{REFERENCES}

1. Ahn S H, et al. Chronic hepatitis B: whom to treat and for how long? Propositions, challenges, and future directions. Hepatology International 2010; 4: 386-395.

2. Plymoth A, Viviani S, Hainaut P. Control of hepatocellular carcinoma through hepatitis $\mathrm{B}$ vaccination in areas of high endemicity: perspectives for global liver cancer prevention. Cancer Letters 2009; 286: 15-21.

3. Fung J, Lai CL, Yuen MF. Hepatitis B and C virusrelated carcinogenesis. Clinical Microbiology and Infection 2009 ; 15: 964-970.

4. Kao JH, et al. Universal hepatitis B vaccination and the decreased mortality from fulminant hepatitis in infants in Taiwan. Journal of Pediatrics 2001; 139: 349-352.

5. Montesano R. Hepatitis B immunization and hepatocellular carcinoma; The Gambia Hepatitis Intervention Study. Journal of Medical Virology 2002; 67: 444-446.

6. Chang MH, et al. Decreased incidence of hepatocellular carcinoma in hepatitis B vaccinees: a 20 year follow-up. Journal of the National Cancer Institute 2009; 101: 1348-1355.

7. Brook MG, et al. Antenatal screening for hepatitis B is medically and economically effective in the prevention and vertical transmission: three years experience in a London. Quarterly Journal of Medicine 1989; 71: 313-317.

8. Dwyer MJ, McIntyre PG. Antenatal screening for hepatitis B surface antigen: an appraisal of its value in a 
low prevalence area. Epidemiology and Infection 1996; 117: 121-131.

9. Jordan R, Law M. An appraisal of the efficacy and cost effectiveness of antenatal screening for hepatitis B. Journal of Medical Screening 1997; 4: 117-127.

10. Balogun MA, et al. Acute hepatitis B infection in England and Wales: 1985-1996. Epidemiology and Infection 1999; 122: 125-133.

11. Hahné S. et al. Incidence and routes of transmission of hepatitis B virus in England and Wales, 1995-2000: implications for immunisation policy. Journal of Clinical Virology 2004; 29: 211-220.

12. Hurie MB, Mast EE, Davis JP. Horizontal transmission of hepatitis B infection to United States born children of Hmong refugees. Pediatrics 1992; 89: 269-273.

13. Diel R, Helle J, Gottschalk R. Transmission of hepatitis B in Hamburg, Germany, 1998-2002 a perspective population based study. Medical Microbiology and Immunology 2005; 194: 193-199.

14. Davis LG, Weber DJ, Lemon SM. Horizontal transmission of hepatitis B virus. Lancet 1989; 1: 889-893.

15. Martinson FE, et al. Risk factors for horizontal transmission of hepatitis B virus in a rural district in Ghana. American Journal of Epidemiology 1998; 147: 478-487.

16. Doganci T, et al. Horizontal transmission of hepatitis B virus in children with chronic hepatitis $\mathrm{B}$. The World Journal of Gastroenterology 2005; 11: 418-420.

17. Hahné S, et al. Hepatitis B incidence among South Asian children in England and Wales: implications for immunisation policy. Archives of Disease in Childhood $2003 ; 88$ : 1082-1083.

18. Değertekin H, Tuzcu A, Yalçin K. Horizontal transmission of HBV infection among students in Turkey. Public Health 2000; 114: 411-412.

19. Mckie A, Vyse A, Maple C. Novel methods for the detection of microbial antibodies in oral fluid. Lancet Infectious Diseases 2002; 2: 18-24.

20. Vyse AJ, Cohen BJ, Ramsay ME. A comparison of oral fluid collection devices for use in the surveillance of virus diseases in children. Public Health 2001; 115: 201-207.

21. Chatzipantazi $\mathbf{P}$, et al. The feasibility and acceptability of collecting oral fluid from healthy children for antiHCV testing. Archives of Disease in Childhood 2004; 89: 185-187.

22. Parry JV, et al. Diagnosis of hepatitis A and B by testing saliva. Journal of Medical Virology 1989; 28: 255-260.

23. Parry J. Simple and reliable salivary tests for HIV and hepatitis A and B virus diagnosis and surveillance. Annals of the New York Academy of Sciences 1993; 694 : 216-233.

24. Thornton L, et al. Comparison between self-reported hepatitis B, hepatitis C, and HIV antibody status and oral fluid assay results in Irish prisoners. Communicable Disease and Public Health 2000; 3: 253-255.

25. Parry JV, Perry KR, Mortimer PP. Sensitive assays for viral antibodies in saliva: an alternative to tests on serum. Lancet $1987 ; 2$ : 72-75.
26. Yusof JH, Flower AJ, Teo CG. Transmission of hepatitis B virus analyzed by conformation-dependent polymorphisms of single-stranded viral DNA. Journal of Infectious Diseases 1994; 169: 62-67.

27. Hesketh LM, et al. Childhood infection with hepatitis A and $\mathrm{B}$ viruses in England and Wales. Communicable Disease Report 1997; 7: R60-R63.

28. Franks AL, et al. Hepatitis B virus infection among children born in the United States to Southeast Asian refugees. New England Journal of Medicine 1989; 321: 1301-1305.

29. Mahoney FJ, et al. Continuing risk for hepatitis B virus transmission among Southeast Asian infants in Louisiana. Pediatrics 1995; 96: 1113-1116.

30. Yao GB. Importance of perinatal versus horizontal transmission of hepatitis B virus infection in China. Gut 1996; 38: S39-S42.

31. Hsu SC, et al. Horizontal transmission of hepatitis B virus in children. Journal of Pediatric Gastroenterology and Nutrition 1993; 16: 66-69.

32. Martinson FE, et al. Risk factors for horizontal transmission of hepatitis B virus in a rural district in Ghana. American Journal of Epidemiology 1998; 147: 478-487.

33. Kawsar M, Goh BT. Hepatitis B virus infection among Chinese residents in the United Kingdom. Sexually Transmitted Infections 2002; 78: 166-168.

34. Aweis D, et al. Hepatitis B prevalence and risk factors for HBsAg carriage amongst Somali households in Liverpool. Communicable Disease and Public Health $2001 ; 4: 247-252$.

35. Gjørup IE, et al. Changing epidemiology of HBV infection in Danish children. Journal of Infection 2003; 47: 231-235.

36. Fisker N, et al. Low hepatitis B prevalence among preschool children in Denmark: saliva anti-HBc screening in day care centres. Journal of Medical Virology 2002; 68: 500-504.

37. Burgess MA, et al. Hepatitis B in urban Australian schoolchildren. No evidence of horizontal transmission between high-risk and low risk groups. Medical Journal of Australia 1993; 159: 315-319.

38. Repp R, et al. Risk of hepatitis B transmission in school. Lancet 1994 ; 344: 961-962.

39. Hayashi $\mathbf{J}$, et al. Hepatitis B virus transmission in nursery schools. American Journal of Epidemiology 1987; 125: 492-498.

40. Goldstein ST, et al. Incidence and risk factors for acute heparitis B in the United States 1982-1998 implications for vaccination program. Journal of Infectious Diseases 2002; 185: 713-719.

41. Ramsay M, et al. Control of hepatitis B in the United Kingdom. Vaccine 1998; 16 (Suppl.) S52-S55.

42. Lindh M, et al. Hepatitis B carriers in Sweden: effects of immigration. Scandinavian Journal of Infectious Diseases 1993; 25: 411-416.

43. Veldhuijzen IK, et al. Screening and early treatment of migrants for chronic hepatitis $\mathrm{B}$ virus infection Is cost-effective. Gastroenterology 2010; 138: $522-530$. 
44. Tilson L, et al. Cost effectiveness of hepatitis B vaccination strategies in Ireland: an economic evaluation. European Journal of Public Health 2007; 18: 275-282.

45. Edmunds WJ. Universal or selective immunisation againsthepatitis B virus in the United Kingdom? A review of recent cost-effectiveness studies. Communicable Disease and Public Health 1998; 1: 221228.

46. Etuwewe O, Wood A, Lyon A. Delivering a selective neonatal BCG vaccination programme in a multi-ethnic community: an audit of the neonatal BCG immunisation programme in Birmingham and Solihull. Communicable Disease and Public Health 2004; 7: $172-176$.
47. Galama JM. National hepatitis B vaccination closer to implementation but not soon enough: recommendation s from the Dutch Health Council. Nederlands Tijdschrift voor Geneeskunde 2001; 145: 1339-1342.

48. Gay NJ, Edmunds WJ. Developed countries could pay for hepatitis B vaccination in developing countries. British Medical Journal 1998; 316: 1457.

49. Larcher VF, et al. Overcoming barriers to hepatitis B immunisation by a dedicated hepatitis B immunisation service. Archives of Disease in Childhood 2001; 84: 114-119.

50. Giraudon I, et al. Factors associated with incomplete vaccination of babies at risk of perinatal hepatitis B transmission: a London study in 2006. Vaccine 2009; 27: 2016-2022. 